\title{
MEDIA DEMONSTRASI KIMIA YANG DIMODIFIKASI UNTUK MENGATASI MISKONSEPSI MAHASISWA PADA TOPIK SEL ELEKTROKIMIA
}

\section{MODIFIED CHEMISTRY DEMONSTRATION TO OVERCOME STUDENT'S MISCONCEPTION IN TOPIC OF ELECTROCHEMICAL CELL}

\author{
Muti'ah $^{1)}$, Jackson Siahaan ${ }^{2)}$, dan Sukib ${ }^{3)}$ \\ 1) 2) 3) Program Studi. Pend. Kimia, PMIPA, FKIP Unram \\ Universitas Mataram, Jalan Majapahit No.62, Mataram, Indonesia \\ Email: muti’ah@unram.ac.id
}

Received: 11 Maret 2017; Accepted: 28 Maret 2017

\begin{abstract}
Abstrak: Tujuan penelitian ini untuk menyelidiki penerapan media demonstrasi kimia yang dimodifikasi untuk mengatasi miskonsepsi mahasiswa pada topik sel elektrokimia. Penelitian dilaksanakan menggunakan penelitian tindakan kelas berbasis lesson study yang dilaksanakan selama 2 siklus, yaitu siklus I menggunakan metode konvensional dan siklus II media demonstrasi kimia yang dimodifikasi.

Hasil penelitian menunjukan bahwa miskonsepsi mahasiswa pada topik sel elektrokimia terkait dengan konsep transfer elektron, pembawa muatan listrik dalam rangkaian luar/kawat penghantar, mekanisme aliran listrik dalam larutan elektrolit dan jembatan garam, serta mekanisme aliran elektron maupun aliran listrik dalam sel galvani. Penerapan media demonstrasi kimia yang dimodifikasi dapat meningkatkan pemahaman konsep. Hal ini terbukti adanya peningkatan persentase mahasiswa yang mampu memperbaiki miskonsepsi, yaitu: transfer elektron $15 \%$, pembawa muatan listrik dalam rangkaian luar/kawat penghantar 34\%, mekanisme aliran listrik dalam larutan elektrolit dan jembatan garam 20\%, mekanisme aliran elektron maupun rangkaian aliran listrik dalam sel galvani $25 \%$ dan $18 \%$

Dari hasil penelitian ini dapat disimpulkan bahwa media demosntrasi kimia yang dimodifikasi dapat mengatasi miskonsepsi karena merupakan cara pembelajaran yang dapat menyajikan fenomena kimia pada tingkat makroskopis, submikroskopis dan simbolik.
\end{abstract}

\section{Kata kunci: demonstrasi kimia dimodifikasi, miskonsepsi, sel elektrokimia}

Abstract. The goal of the research is to investigate the application of modified chemistry demonstration in order to overcome student's misconception on the topic electrochemical cell. This work has done by implementation of class room action research base on lesson study in two cycles. Cycles I implemented conventional method learning and cycles II implemented modified chemistry demonstration.

Result of this research shows that student's misconception on the topic of electrochemical cell involve with electron transfer concept, electrical charge carrier in outer circuit/conductor, electrical current mechanism in electrolyte solution and salt bridge, and electron current mechanism or electrical current in galvanic cell.

Implementation of modified chemistry demonstration is able to improve student's comprehension. This is proven by increasing of percentage of students who able to overcome misconception, such as: electron transfer $15 \%$, electrical charge carrier in outer circuit/conductor $34 \%$, electrical current mechanism in electrolyte solution and salt bridge $20 \%$, electron current mechanism or electrical current in galvanic cell $25 \%$, and $18 \%$ respectively.

From this result, it can be concluded that modified chemistry demonstration is able to overcome student's misconception since this method is a way to learn that is able to give chemistry phenomena on the level macroscopic, submicroscopic, and symbolic.

\section{Keywords: modified chemistry demonstration, misconception, electrochemical cell}

\section{PENDAHULUAN}

Penguasaan konsep kimia dasar bagi mahasiswa tingkat pertama sangat diperlukan, karena menjadi dasar dalam memahami ilmu kimia secara umum maupun kimia lanjut [1]. Topik-topik esensial pada matakuliah kimia dasar terutama adalah sel elektrokimia, termokimia, kesetimbangan kimia, stiokhiometri, struktur atom dan molekul, serta laju reaksi [2],[3]. Namun demikian dari hasil refleksi tim pengajar selama melakukan pembelajaran di kelas menunjukan bahwa " perhatian siswa cukup rendah dan banyak terjadi miskonsepsi”. Selanjutnya menurut Garnett dan Treagust miskonsepsi siswa disebabkan sebagian besar fenomena/konsep ilmu kimia bersifat abstrak [4]

Treagust mengklasifikasikan fenomena/konsep kimia pada tiga tingkat representasi; yaitu tingkat makroskopik, submikroskopik, dan simbolik, dimana ketiganya saling memiliki keterkaitan [5]. Kemudian 
dijelaskan pula bahwa tingkat makroskopik merupakan fenomena nyata yang dapat secara langsung diamati dan dapat dirasakan oleh panca indera, tingkat submikroskopik merupakan fenomena nyata, tetapi memerlukan teori untuk menjelaskan pada tingkat molekuler dan atomik. Selanjutnya tingkat simbolik merupakan representasi dari fenomena nyata yang dinyatakan dalam bentuk gambar, simbol/rumus kimia, persamaan reaksi, grafik, maupun mekanisme reaksi.

Kozma dan Russell menyatakan bahwa representasi submikroskopik merupakan faktor kunci, artinya ketidakmampuan dalam merepresentasikan aspek submikroskopik akan menghambat kemampuan memecahkan permasalahan yang terkait dengan fenomena tingkat makroskopik dan simbolik [6]. Oleh karena itu Chandrasegaran menyarankan untuk menggunakan strategi dan kondisi pembelajaran kimia dalam bentuk representasi makroskopik, mikroskopik, dan simbolik secara simultan/ bersamaan [7].

Pembelajaran yang dapat merepresentasikan ketiga tingkatan tersebut secara simultan telah diterapkan oleh Muti'ah, Loka, dan Sukib yaitu metode demonstrasi kimia yang dimodifikasi pada perkuliahan Chemical Separation [8]. Prinsip dari metode tersebut adalah memadukan media demonstrasi kimia dengan media power point yang memuat gambar, rumus kimia, persamaan reaksi, grafik, dan konsep-konsep terkait. Kaitan pembelajaran tersebut dengan perbaikan miskonsepsi sejalan dengan konstruksi model mental, dalam hal ini media demonstrasi terkait dengan konstruksi pada tingkat makroskopis dan media power point/animasi terkait dengan konstruksi di tingkat submikroskopis dan simbolik [9]. Selain itu juga dijelaskan oleh Milne dan Otieno bahwa pembelajaran dengan media demonstrasi kimia mampu membangkitkan perhatian, motivasi siswa, dan mengatasi miskonsepsi [10]

Terkait dengan permasalahanpermasalahan yang terjadi selama pembelajaran kimia dasar, maka dirasakan sangat perlu untuk menerapkan pembelajaran dengan media demonstrasi yang dimodifikasi. Hal ini terkait dengan penelitian terdahulu Muti'ah dan Sukib yang menyatakan tingginya miskonsepsi mahasiswa dalam memahami konsep elektrokimia, terutama reaksi redoks, sifat elektroda, aliran arus listrik pada rangkaian luar, aliran arus listrik melalui rangkaian dalam, dan fungsi jembatan garam [11]. Selain itu hasil penelitian Muti'ah. Loka, dan Sukib juga menunjukkan bahwa demonstrasi kimia hanya mampu membangkitkan perhatian dan motivasi, tetapi belum mampu mengatasi miskonsepsi [8]

Tujuan dari artikel ini adalah menyusun dan membuktikan bahwa media demonstrasi kimia yang modifikasi mampu mengatasi miskonsepsi mahasiswa pada topik sel elektrokimia. Dengan penelitian ini diharapkan mahasiwa dapat memahami konsep kimia terutama sel elektrokimia dengan benar sehingga dapat digunakan sebagai dasar dalam mengkaji ilmim kimia lanjutan.

\section{METODE PENELITIAN}

Sampel yang digunakan (subyek) dalam penelitian Mahasiswa Prog. Studi Pendidikan Kimia, FMIPA, FKIP Unram yang mengikuti matakuliah kimia dasar (topik sel elektrokimia). Obyek penelitian ini adalah perhatian dan kemampuan mahasiswa dalam memahami konsep sel elektrokimia setelah diterapkan pembelajaran dengan menggunakan media demonstrasi kimia yang dimodifikasi.

Penelitian ini diracang dengan menggunakan penelitian tindakan kelas dengan pendekatan lesson study. Tindakan yang diterapkan adalah penggunaan media "demonstrasi kimia yang dimodifikasi". Penelitian dilaksanakan selama 2 siklus, yaitu siklus I pembelajaran dengan metode konvensipnal dan siklus II media demonstrasi yang dimodifikasi pada topik sel elektrokimia.

Oleh karena penelitian ini menggunakan pendekatan lesson study, maka tahapan yang dilakukan adalah perencanaa, pelaksanaan, dan refleksi. Perencanaan meliputi penyusunan perangkat pembelajaran (RPP, power point, animasi, lembar kerja mahasiswa, tes) dan media demonstrasi kimia. Penyusunan/pembuatan media demosntrasi kimia dilakukan di Laboratorium Kimia, Jurusan PMIPA FKIP Unram. Demonstrasi kimia mengacu pada pada Cheung [12] serta Tarhan dan Acar [13] [17]. Hubungan antara konsep yang dijelaskan dengan media disajikan pada tabel 1 .

Pelaksanaan penelitian meliputi pembelajaran di kelas dengan metode konvensional dan dilanjutkan dengan media demonstrasi kimia yang dimodifikasi. Tahap refleksi merupakan tahapan untuk menganalisis dan mengevaluasi hasil pembelajaran. Data yang diungkap dalam penelitian ini merupakan data kuantitatif dan kualitatif. Data kuantitatif terutama tingkat pemahaman konsep kimia dasar mahasiswa berdasarkan tes hasil belajar pada topik sel elektrokimia. Data kualitatif berupa analisis pengaruh media terhadap perbaikan konsep terkait dengan model mental siswa yang dijelaskan secara naratif. 
Table1 1. Jenis konsep yang dijelaskan dan media yang digunakan

\begin{tabular}{|c|c|}
\hline Konsep yang dijelaskan & Nama Media \\
\hline $\begin{array}{l}\text { Pengertian oksidasi dan reduksi, sifat dan fungsi } \\
\text { elektroda, aliran arus listrik dan hubungannya dengan } \\
\text { kawat penghantar, larutan elektrolit dan jembatan } \\
\text { garam }\end{array}$ & $\begin{array}{l}\text { 1. } \quad \text { Reaksi redoks } \\
\text { 2. } \quad \text { Sel elektrokimia }\end{array}$ \\
\hline
\end{tabular}

\section{HASIL DAN PEMBAHASAN}

\subsection{Miskonsepsi Mahasiswa pada Topik Sel Elektrokimia}

Konsep sel elektrokimia yang diuji pada mahasiswa berjumlah 14 konsep sebagaimana tercantum dalam tabel 2. Data pada tabel 2 menunjukan persentase mahasiswa yang menjawab pertanyaan-pertanyaan/konsep dengan benar. Berdasarkan data pada tabel 2 dapat diinformasikan bahwa miskonsepsi mahasiswa pada siklus I paling tinggi terdapat pada konsep penerapan sel elektrokimia $2 \%$, dan diikuti transfer elektron $8 \%$, aliran elektron dalam sel galvani $16 \%$, mekanisme aliran listrik dalam jembatan garam, 30\%, dan pembawa muatan listrik pada rangkaian luar $44 \%$. Konsep lainnya tergolong sedang dan rendah.

Miskonsepsi siswa dalam memahami transfer elektron dalam reaksi redoks disebabkan oleh ketidakmampuan siswa dalam menentukan bilangan oksidasi masing-masing zat yang terlibat (reduktor dan oksidator), sehingga kesulitan dalam memperkirakan zat mana yang melepas dan menangkap elektron. Sebagai contoh untuk persamaan reaksi berikut:

$$
\mathrm{Mg}_{(\mathrm{s})}+2 \mathrm{HCl}_{(\mathrm{aq})} \rightarrow 2 \mathrm{MgCl}_{2 \mathrm{aq})}+\mathrm{H}_{2(\mathrm{~g})}
$$

Sebagian besar mahasiswa menjawab "transfer elektron terjadi dari dari $\mathrm{Mg} \mathrm{ke} \mathrm{Cl}$, karena $\mathrm{Cl}$ bersifat elektronegatif". Apa yang ada dalam pikiran siswa adalah sifat dari atom $\mathrm{Mg}$ elektropositif dan $\mathrm{Cl}$ elektronegatif. Kesalahan mahasiswa tersebut menunjukkan adanya kegagalan siswa dalam mengasimilasi pengalaman baru dengan skema/struktur yang telah dimiliki sebagaimana diungkap dalam teori Piaget bahwa aktivitas individu dilakukan melalui proses asimilasi dan akomodasi yang berlangsung terus menerus sampai ketika dewasa [14]. Secara kualitatif miskonsepsi mahasiswa pada konsep sel elektrokimia dapat ditunjukan dalam tabel 3.

Miskonsepsi mahasiswa pada konsep "pembawa muatan listrik dalam rangkaian luar" tergolong tinggi, karena sebagian besar mahasiswa menjawab "muatan listrik dalam rangkaian luar dibawa oleh kation dan anion". Hal ini menunjukkan bahwa siswa belum dapat membedakan antara rangkaian luar (kawat penghantar) dan rangkaian dalam (larutan elektrolit-jembatan garam). Dalam konsep ini siswa tidak memahami atribut konsep aliran listrik pada kawat penghantar terutama adalah ikatan logam dan sifat hantaran dari logam. Di samping itu siswa tidak memahami atribut sifat muatan listrik bahwa muatan listrik terdiri dari muatan negatif yang dibawa oleh elektron atau anion dan muatan positif yang dibawa oleh kation (dalam pengantar logam proton tidak mengalami pergerakan). Kesulitan siswa dalam menjelaskan transfer elektron juga telah ditemukan oleh peneliti terdahulu [3][15][17].

Miskonsepsi siswa pada konsep mekanisme aliran listrik dalam larutan elektrolit dan jembatan garam cukup tinggi (48\% menjawab benar). Miskonsepsi ditunjukan oleh jawaban siswa bahwa arus listrik dalam larutan dan jembatan garam dibawa oleh: elektron terikat oleh molekul $\mathrm{H}_{2} \mathrm{O}$, elektron bebas, elektron terikat oleh molekul air sebagai larutan elektron. Kesalahan konsep tersebut dapat bersumber dari gambar yang terdapat dalam buku, misalnya adalah suatu ion bentuk bola yang bertanda negatif. Siswa tidak memahami bahwa pembawa muatan listrik dalam larutan adalah ion - ion [15],[17].

$$
\text { Miskonsepsi siswa pada konsep }
$$
mekanisme aliran elektron dalam sel galvanik cukup tinggi (16\% menjawab benar). Salah satu jawaban siswa adalah elektron mengalir dari $\mathrm{Cu}$ ke $\mathrm{Zn}$. Miskonsepsi pada konsep ini disebabkan kurang menguasai atribut atau subkonsep yang menyusunnya, yaitu sumber elektron (reaksi dan sifat elektroda), fungsi jembatan garam, aliran matan listrik dalam kawat, larutan, dan jembatan garam, hukum ohm terkait rangkaian arus listrik dalam rangkaian tertutup.

Apabila siswa telah memahami atribut/subkonsep tersebut, maka siswa dapat menjelaskan bahwa arus listrik merupakan aliran muatan listrik dalam rangkaian tertutup, sehingga muatan listrik mengalir dari dari logam Zn-kawatlogam $\mathrm{Cu}$ - larutan I-jembatan garam-larutan II logam Zn. Hasil penelitian tersebut di atas juga sesuai dengan hasil penelitian yang dilakukan peneliti terdahulu [16] [4]. Hasil penelitian yang diperolehnya hampir sama dengan hasil penelitian ini, yaitu kesulitan siswa dalam menjelaskan aliran listrik dalam rangkaian luar dan dalam. Pada umumnya siswa beranggapan bahwa arus dapat mengalir tanpa rangkaian tertutup dan beberapa siswa juga menganggap bahwa elektron dapat mengalir secara sempurna dalam rangkaian tersebut. Akibatnya siswa menyatakan bahwa 
"aliran elektron diawali dari anoda ke katoda melalui kawat, kemudian lepas ke dalam larutan elektrolit melalui katoda, kemudian bergerak/berpindah melalui larutan elektrolit dan jembatan garam kemudian mencapai anoda".

Tabel 2. Persentase mahassiwa menjawab benar pada konsep sel elektrokimia

\begin{tabular}{|clccc|}
\hline \multirow{2}{*}{ No } & & \multicolumn{2}{c}{ Konsep yang diteliti } & Beda \\
\cline { 3 - 4 } & & Siklus I & Siklus II & \\
\hline 1 & Identifikasi reaksi redoks & $93^{*}$ & $93^{*}$ & 0 \\
2 & Transfer elektron dalam reaksi redoks & $8^{* *}$ & $23^{* *}$ & 15 \\
3 & Pengertian oksidator - reduktor & 68 & $75^{*}$ & 8 \\
4 & Pengertian nilai potensial reduksi standar $E_{\text {red }}^{o}$ & $90^{*}$ & $93^{*}$ & 3 \\
5 & Intepretai nilai potensial reduksi standar & 73 & $90^{*}$ & 18 \\
6 & Konsep dasar kelistrikan: hukum coulomb & 60 & $78^{*}$ & 18 \\
7 & Reaksi yang terjadi pada elektroda dalam sel & & & \\
& Galvani & 63 & 73 & 10 \\
8 & Identifikasi jenis katoda & $78^{*}$ & $95^{*}$ & 18 \\
9 & Sifat elektroda & $88^{*}$ & $80^{*}$ & -8 \\
10 & Rangkaian arus listrik dalam sel elektrokimia & & & \\
& (rangkaian tertutup) & 68 & $85^{*}$ & 18 \\
11 & Pembawa muatan listrik dalam rangkaian luar & $44^{* *}$ & $78^{*}$ & 34 \\
12 & Aliran elektron dalam sel Galvani & $16^{* *}$ & $36^{* *}$ & 25 \\
13 & Mekanisme aliran listrik dalam larutan elektrolit & & & \\
& dan jembatan garam & $30^{* *}$ & 52 & 20 \\
14 & Penerapkan konsep sel elektrokimia & $2^{* *}$ & 18 & 16 \\
\hline
\end{tabular}

Keterangan:* (miskonsepsi rendah, >75\%), tanpa tanda bintang (miskonsepsi sedang, 50\% - 75\%), dan **(miskonsepsi tinggi, <50\%),

Tabel 3. Miskonsepsi mahasiswa tergolong tinggi

\begin{tabular}{|c|c|}
\hline Konsep & Miskonsepsi \\
\hline $\begin{array}{l}\text { Transfer elektron } \\
(8 \%)\end{array}$ & $\begin{array}{l}\text { Dalam reaksi } \mathrm{Mg}(\mathrm{s})+\mathrm{HCl}(\mathrm{aq}) \rightarrow \mathrm{MgCl}_{2}+\mathrm{H}_{2}(\mathrm{~g}) \text {, proses yang terjadi } \\
\text { atom } \mathrm{Mg} \text { melepas } 2 \text { elektron dan elektron tersebut diterima oleh } \mathrm{Cl} \\
\text { sebab } \mathrm{Cl} \text { merupakan atom elektronegatif } \\
\text { Atom } \mathrm{Mg} \text { melepas } 2 \text { elektron dan elektron tersebut diterima oleh } \\
\text { hidrogen (ion) }\end{array}$ \\
\hline $\begin{array}{l}\text { Pembawa muatan listrik } \\
\text { dalam rangkaian luar } \\
(44 \%)\end{array}$ & $\begin{array}{l}\text { Muatan listrik dalam rangkaian luar/kawat dibawa oleh kation dan } \\
\text { anion } \\
\text { Muatan listrik dalam rangkaian luar/kawat dibawa oleh elektron }\end{array}$ \\
\hline $\begin{array}{l}\text { Mekanisme aliran listrik } \\
\text { dalam larutan elektrolit } \\
\text { dan jembatan garam } \\
(48 \%)\end{array}$ & $\begin{array}{l}\text { Arus listrik dalam larutan dan jembatan garam dibawa oleh elektron } \\
\text { yang terikat oleh molekul } \mathrm{H}_{2} \mathrm{O} \text { sebagai larutan elektron } \\
\text { Arus listrik dalam larutan dan jembatan garam dibawa oleh elektron } \\
\text { yang terikat oleh ion positif (kation) } \\
\text { Arus listrik dalam larutan dan jembatan garam dibawa oleh ion- } \\
\text { ion, yaitu ion positif bergerak menuju katoda sedangkan ion negatif } \\
\text { bergerak menuju anoda }\end{array}$ \\
\hline $\begin{array}{l}\text { Mekanisme aliran } \\
\text { elektron dalam sel } \\
\text { Galvanik }(16 \%)\end{array}$ & $\begin{array}{l}\text { Elektron mengalir dari logam } \mathrm{Zn}-\text { kawat }- \text { logam } \mathrm{Cu}-\text { larutan }- \\
\text { jembatan garam - larutan - logam } \mathrm{Zn} \\
\text { Elektron mengalir hanya dari logam } \mathrm{Zn}-\text { kawat - Logam Cu }\end{array}$ \\
\hline $\begin{array}{l}\text { Penerapan } \\
(2 \%)\end{array}$ & $\begin{array}{l}\text { Y adalah elektroda }(+) \text { dimana terjadi reaksi reduksi } \\
\text { Logam } X \text { dicelupkan dalam larutan } X^{2+} \text { dan Y adalah elektroda }(+) \\
\text { dimana terjadi reaksi reduksi }\end{array}$ \\
\hline
\end{tabular}


Ada beberapa siswa juga beranggapan bahwa anion dalam larutan elektrolit dan jembatan garam berfungsi untuk mentransfer elektron dari katoda ke anoda. Miskonsepsi yang terjadi pada konsep aliran mualatn listrik dalam larutan elektrolit dan jembatan garam, juga sesuai dengan hasil penelitian yang dilakukan oleh peneliti terdahulu [17], [13]

Miskonsepsi pada bagian penerapan sel elektrokimia sangat tinggi (hanya $2 \%$ menjawab benar) hal ini terkait dengan tidak dikuasainya konsep dasar sel elektrokimia, yaitu definisi potensial elektroda dan adanya sel elektrokimia yang menggunakan elektroda inert, misalnya Pt dan karbon.

\subsection{Media Demonstrasi Kimia yang Dimodifikasi}

Pembelajaran menggunakan media demonstrasi kimia yang dimodifikasi dalam penelitian ini pada dasarnya merupakan perpaduan secara simultan antara media demonstrasi kimia dengan power point/animasi. Metode pembelajaran ini dapat menjelaskan fenomena/konsep kimia pada tiga tingkat representasi; yaitu tingkat makroskopik, submikroskopik, dan simbolik [5]. Fenomena tingkat makroskopis, submikroskopis dan simbolik pada konsep sel elektrokimia disajikan pada gambar 1 .

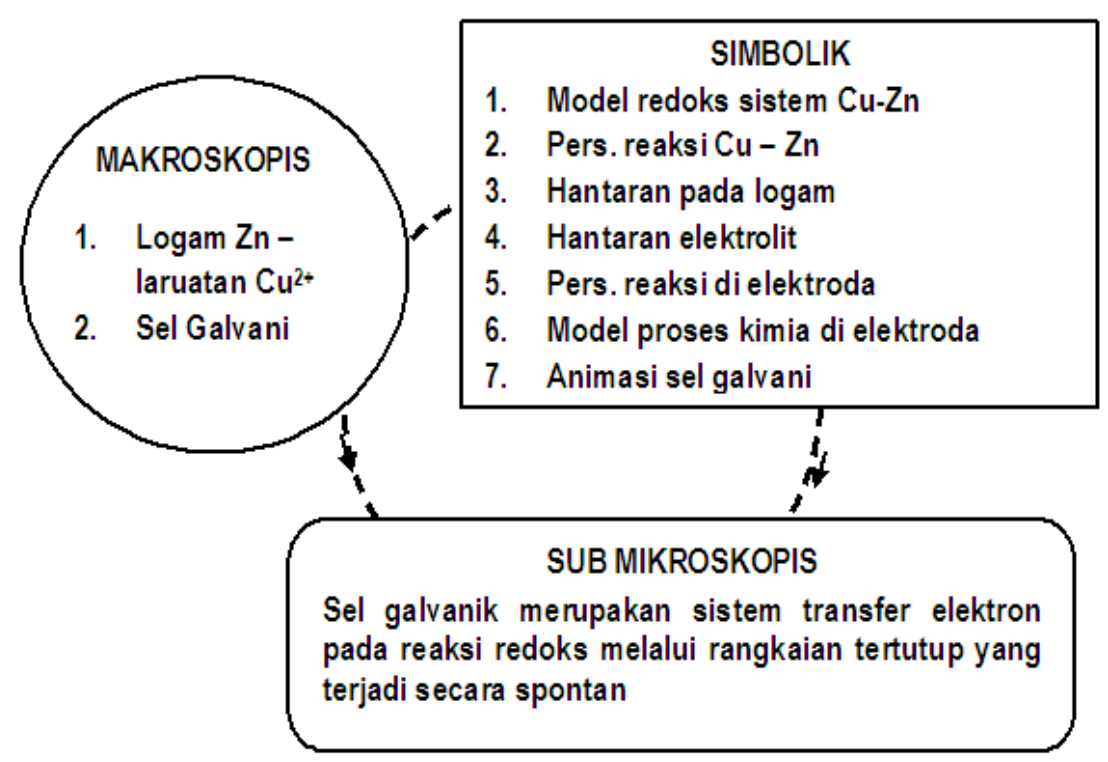

Gambar 1. Representasi fenomena sel galvani pada tingkat makroskopis, sub mikroskopis dan simbolik

Fenomena tingkat makroskopis disajikan dalam sebuah demonstrasi reaksi redoks sistem $\mathrm{Cu}-\mathrm{Zn}$ dan sel galvani sistem $\mathrm{Cu}-\mathrm{Zn}$. Fenomena simbolik disajikan dalam power point dan animasi. Sebagai contoh fenomena simbolik dalam penelitian ini adalah reaksi redoks $\mathrm{Cu}-\mathrm{Zn}$ rangkaian terbuka yang menggambarkan terjadinya oksidasi-reduksi secara mikroskopis (gambar 2).

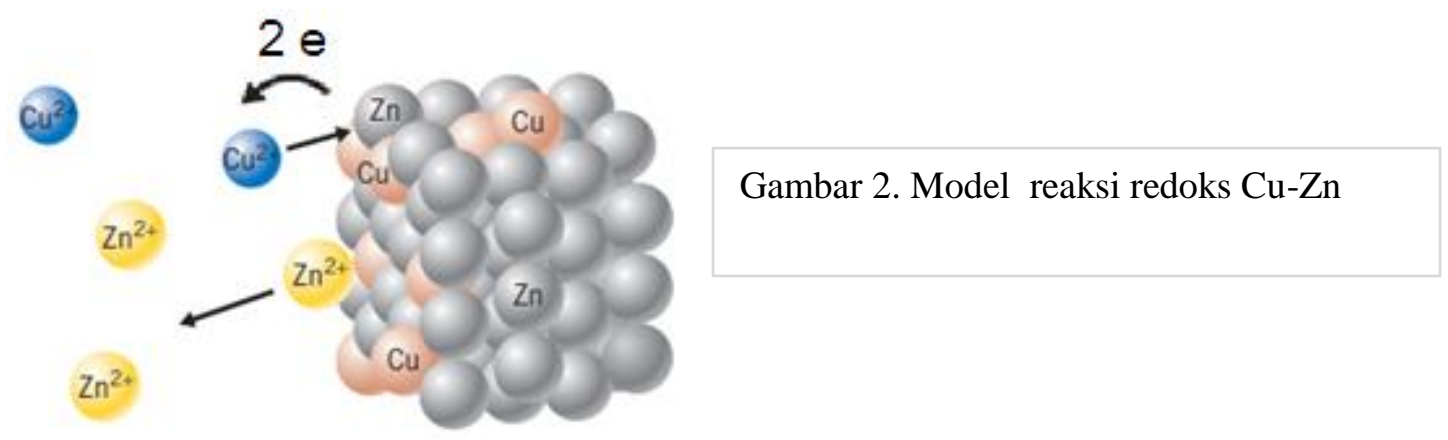


Gambar 2 merupakan fenomena kimia pada tingkat simbolis dimana reaksi oksidasi atom $\mathrm{Zn}$ menjadi $\mathrm{Zn}^{2+}$ dan reduksi $\mathrm{Cu}^{2+}$ menjadi atom $\mathrm{Cu}$ dapat digambarkan dalam bentuk bola dengan warna berbeda. Dalam model ini terjadinya reaksi redoks digambarkan secara spontan atom $\mathrm{Zn}$ berubah menjadi ion $\mathrm{Zn}^{2+}$ dan 2 elektron, kemudian 2 elektron tersebut ditangkap oleh ion $\mathrm{Cu}^{2+}$ sehingga berubah menjadi atom $\mathrm{Cu}$. Melalui penyajian ini maka model mental siswa tentang reaksi redoks sistem $\mathrm{Cu}-\mathrm{Zn}$ akan lebih jelas dibandingkan bila hanya menulis $\mathrm{Zn}$ teroksidasi dan $\mathrm{Cu}^{2+}$ tereduksi Oleh karena penerapan metode demonstrasi kimia yang dimodifikasi dapat menyajikan ketiga fenomena tersebut, maka pembelajaran lebih berkualitas atau dapat meningkatkan pemahaman konsep sebagaimana data tabel 2 [7]. Hasil analsis perubahan konsep siswa setelah penerapan metode tersebut tercantum dalam tabel 4 .

Tabel 4. Perubahan konsep mahasiswa sebelum dan sesudah penerapan media

\begin{tabular}{|c|c|}
\hline Sebelum pembelajaran & Sesudah Pembelajaran \\
\hline $\begin{array}{l}\text { 1) Atom } \mathrm{Mg} \text { melepas } 2 \text { elektron dan elektron } \\
\text { tersebut diterima oleh atom } \mathrm{Cl} \text { sebab atom } \\
\text { Cl merupakan atom elektronegatif }\end{array}$ & $\begin{array}{l}\text { 1) Atom } \mathrm{Mg} \text { melepas } 2 \text { elektron dan elektron } \\
\text { tersebut diterima oleh hidrogen (ion } \\
\text { hidrogen) }\end{array}$ \\
\hline $\begin{array}{l}\text { 2) Muatan listrik dalam rangkaian luar/kawat } \\
\text { dibawa oleh kation dan anion }\end{array}$ & $\begin{array}{l}\text { 2) Muatan listrik dalam rangkaian luar/kawat } \\
\text { dibawa oleh elektron }\end{array}$ \\
\hline $\begin{array}{l}\text { 3) Elektron mengalir dari logam } \mathrm{Zn} \text { - kawat } \\
\text { - logam } \mathrm{Cu}-\text { larutan - jembatan garam - } \\
\text { larutan - logam } \mathrm{Zn}\end{array}$ & $\begin{array}{l}\text { 3) Elektron mengalir hanya dari logam } \mathrm{Zn}- \\
\text { kawat - Logam } \mathrm{Cu}\end{array}$ \\
\hline $\begin{array}{l}\text { 4) Arus listrik dalam larutan dan jembatan } \\
\text { garam dibawa oleh elektron yang terikat } \\
\text { oleh ion positif (kation) }\end{array}$ & $\begin{array}{l}\text { 4) Arus listrik dalam larutan dan jembatan } \\
\text { garam dibawa oleh ion - ion, yaitu ion } \\
\text { positif bergerak menuju katoda sedangkan } \\
\text { ion negatif bergerak menuju katoda }\end{array}$ \\
\hline
\end{tabular}

Terjadinya perubahan konsep dari miskonsepsi menjadi konsep ilmiah menunjukan bahwa penggunaan media demonstrasi kimia yang dimodifikasi sesuai dengan prinsip pembentukan model mental siswa [9]. Selain itu metode tersebut melibatkan aktivitas yang cukup tinggi bagi pengajar, sehingga pengajar mempunyai andil yang sangat besar dalam pembentukan model mental siswa [18]. Selanjutnya Chang menyatakan bahwa model mental siswa dibangun dari pengalaman siswa, interpretasi dan penjelasan apa yang mereka lihat, dan refleksi pemahaman mereka pada level sub-mikroskopik [19].

\section{KESIMPULAN}

Miskonsepsi mahasiswa pada topik sel elektrokimia terkait dengan konsep transfer elektron dalam reaksi redoks, pembawa muatan listrik dalam rangkaian luar/kawat penghantar, mekanisme aliran listrik dalam larutan elektrolit dan jembatan garam, serta mekanisme aliran elektron maupun rangkaian aliran listrik dalam sel galvani.

Penerapan media demonstrasi kimia yang dimodifikasi dapat membangun model mental siswa karena merupakan cara pembelajaran yang dapat menyajikan fenomena kimia pada tingkat makroskopis, submikroskopis dan simbolik. Hal ini terbukti adanya peningkatan persentase mahasiswa yang mampu memperbaiki miskonsepsi masingmasing transfer elektron $15 \%$, pembawa muatan listrik dalam rangkaian luar/kawat penghantar 34\%, mekanisme aliran listrik dalam larutan elektrolit dan jembatan garam 20\%, mekanisme aliran elektron maupun rangkaian aliran listrik dalam sel galvani masing-masing $25 \%$ dan $18 \%$

\section{DAFTAR PUSTAKA}

[1] Quilez, J. 2009. From Chemical Forces to Chemical Rates:A Historical Philosophi-cal Foundation for the Teaching of Chemical Equilibrium. Science \& Education, 18:12031251

[2] Niaz, M. 2006. Can the study of thermochemistry facilitate students' differentiation between heat energy and temperature?. Journal of Science Education and Technology, 15(3), 269-276.

[3] Ozkaya, A. R. 2002. Conceptual difficulties experienced by prospective teachers in electrochemistry: Half-cell potential, cell potential, chemical, and electrochemical equilibrium in galvanic cells. Journal of Chemical Education 79: 735-738. 
[4] Garnett, P. J. \& Treagust, D. F. (1992). Conceptual difficulties experienced by senior high school students of electrochemistry: Electrochemical (galvanic) and electrolytic cells. Journal of Research in Science Teaching, 29, 1079-1099

[5] Treagust, D. F., Chittleborough, G., Mamila, T. L. (2002). Students' understanding of the role of scientific models in learning science. International Journal of Science Education, 24 (4): 357- 68.

[6] Kozma, R. B., \& Russell, J. (1997). Multimedia and understanding: Expert and novice responses to different representations of chemical phenomena. Journal of Research in Science Teaching, 34(9), 949-968.

[7] Chandrasegaran, A. L., Treagust, D. F., \& Mocerino, M. (2008). An evaluation of a teaching intervention to promote students' ability to use multiple levels of represen-tation when describing and explaining che-mical reactions. Rese-arch in Science Edu-cation, 38(2), 237-248.
[8] Mutiah, Loka, I.N., dan Sukib. 2012. Pengembangan Metode Demonstrasi Untuk Meningkatkan Kualitas Pembelajaran Chemical Separation Melalui Lesson Study. Laporan Penelitian, Lemlit Unram

[9] Chittleborough, G. D., Treagust, D. F., Mamiala, T. L., \& Mocerino, M. (2005). Students' perceptions of the role of models in the process of science and in the process of learning. Research in Science \& Technological Education, 23(2), 195-212.

[10] Milne, C. \& Otieno, T. (2007). Understanding engagement: Science demonstra-tions and emotional energy. Science Education. 91(4), 523-553.

[11] Muti'ah dan Sukib, 2000. Analisis Kesalahan Konsep dalam topik Konsep Mol, Stoikiometri, dan Reaksi Redoks-elektrokimia pada Matakuliah Kimia Dasar. Laporan Penelitian SPP-DPP, Lemlit Unram

[12] Cheung, D. (2004). The scientific inadequacy of Le Châtelier's principle. Hong Kong Science Teachers' Journal, 22(1), 35-43. 